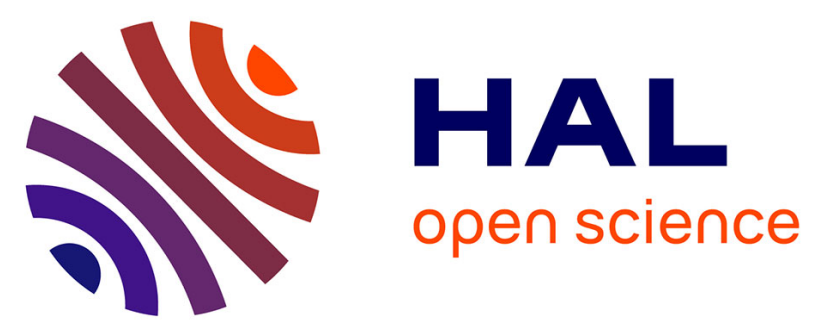

\title{
Nitration of Halterman porphyrin: a new route for fine tuning chiral iron and manganese porphyrins with application in epoxidation and hydroxylation reactions using hydrogen peroxide as oxidant
}

Nesrine Amiri, Paul Le Maux, Hassan Srour, Habib Nasri, Gérard Simonneaux

\section{- To cite this version:}

Nesrine Amiri, Paul Le Maux, Hassan Srour, Habib Nasri, Gérard Simonneaux. Nitration of Halterman porphyrin: a new route for fine tuning chiral iron and manganese porphyrins with application in epoxidation and hydroxylation reactions using hydrogen peroxide as oxidant. Tetrahedron, 2014, 70 (46), pp.8836-8842. 10.1016/j.tet.2014.10.001 . hal-01116078

\section{HAL Id: hal-01116078}

https://hal-univ-rennes1.archives-ouvertes.fr/hal-01116078

Submitted on 2 Jul 2015

HAL is a multi-disciplinary open access archive for the deposit and dissemination of scientific research documents, whether they are published or not. The documents may come from teaching and research institutions in France or abroad, or from public or private research centers.
L'archive ouverte pluridisciplinaire HAL, est destinée au dépôt et à la diffusion de documents scientifiques de niveau recherche, publiés ou non, émanant des établissements d'enseignement et de recherche français ou étrangers, des laboratoires publics ou privés. 
Nitration of Halterman porphyrin: A new route for fine tuning chiral iron and manganese porphyrins with application in epoxidation and hydroxylation reactions using hydrogen peroxide as oxidant.

\author{
Nesrine Amiri, ${ }^{a, b}$ Paul Le Maux, ${ }^{\text {a }}$ Hassan Srour, ${ }^{a}$ Habib Nasrib and Gérard \\ Simonneaux ${ }^{\mathrm{a}_{*}}$ \\ ${ }^{a}$ Institute of Sciences Chimiques of Rennes, Ingénierie Chimique et Molécules pour le vivant \\ UMR 6226 CNRS, Campus de Beaulieu, 35042 Rennes cedex, France \\ ${ }^{b}$ Laboratoire de Physico-chimie des Matériaux, Université de Monastir, Avenue de \\ l'environnement, 5019Monastir, Tunisia
}

\begin{abstract}
A methodology is reported for the regioselective nitration of the phenyl groups of Halterman porphyrin, using $\mathrm{NaNO}_{2}$. These nitroporphyrins can be reduced to aminoporphyrins and then $\mathrm{N}$-dimethylated to give new optically active porphyrins. Applications to the asymmetric epoxidation of styrene derivatives by $\mathrm{H}_{2} \mathrm{O}_{2}$ to give optically active epoxides (ee up to $60 \%$ ) and hydroxylation of alkanes to give optically active secondary alcohols (ee up to 69\%) were carried out in organic solvents (dichloromethane/methanol) using chiral iron and manganese porphyrins as catalysts.

*Corresponding author. E-mail address: gerard.simonneaux@univ-rennes1.fr. Tel 33(0)223236285. Fax: 33(0)223235637.
\end{abstract}

Keywords:

Tetra-nitro-Halterman porphyrin, asymmetric epoxidation, asymmetric hydroxylation, hydrogen peroxide, chiral porphyrins,

\title{
1. Introduction
}

Catalytic asymmetric epoxidation reactions play a major role in organic chemistry since the optically active epoxides are important building blocks. ${ }^{1-3}$ In this context, hydrogen peroxide is a very attractive oxidant for sustainable chemistry. ${ }^{4,5}$ However, catalytic enantioselective oxidations using transition-metal complexes are still limited when the 
oxidant is hydrogen peroxide. $^{6}$ In particular, catalytic asymmetric reactions in aqueous solutions are attractive, but rare. ${ }^{7}$ Recently, there is a revival in developing original and efficient system in asymmetric catalysis. Thus we have now the development of new generations of metal complexes which are able to selectively catalyze various oxidation reactions using $\mathrm{H}_{2} \mathrm{O}_{2}$ as oxidant. ${ }^{3,8,9}$ A novel and general biomimetic non-heme Fe-catalyzed asymmetric epoxidation of aromatic alkenes by using hydrogen peroxide was reported by Beller and co-workers. ${ }^{10,11}$ Other systems including chiral bipyrrolidine ${ }^{12}$ bis-pyridine ${ }^{13}$ and Schiff ${ }^{14}$ base ligands were also described using iron or manganese as the metal in the active site. Chiral bioinspired iron complexes of N4 ligands based on the ethylenediamine backbone display remarkable levels of enantioselectivity for the first time in the asymmetric epoxidation of $\alpha, \beta$-unsaturated ketones using hydrogen peroxide as oxidant (up to $87 \%$ ee). ${ }^{15}$ Epoxidation catalyzed by non-heme iron and manganese complexes has been reviewed in $2012 .{ }^{9}$

The first asymmetric epoxidation catalyzed by chiral porphyrins was reported by Groves and Myers in 1983. ${ }^{16}$ Since then, different chiral iron porphyrins were used by the same author ${ }^{17}$ and others. ${ }^{18-24}$ The oxidant of choice for these systems is generally iodosylbenzene. ${ }^{25}$ It should however be emphasized that the extracellular heme-thiolate peroxygenase from Agrocybe aegerita (AaeAPO) has been shown to catalyze the epoxidation of styrene derivatives and the hydroxylation of alkylbenzenes with high stereoselectivity using hydrogen peroxide as the terminal oxidant. ${ }^{26,27}$

We previously reported enantioselective sulfoxidation ${ }^{28}$ and epoxidation ${ }^{29}$ catalyzed by water-soluble iron porphyrin and enantioselective hydroxylation by water-soluble manganese porphyrins using hydrogen peroxide as oxidant. ${ }^{30}$ In these results, sulfonation of Halterman porphyrin ${ }^{31}$ by sulfuric acid was used to prepare these chiral water-soluble metalloporphyrins. To extend these reactions to organic solvents, preparation of new chiral porphyrins seems to us necessary in order to electronically tune the catalytic activity. ${ }^{25} \mathrm{We}$ herein report the synthesis of a new generation of chiral porphyrins that bear either a nitro, an amino or a dimethylamino group in the 10-position of the 9-[anti-(1,2,3,4,5,6,7,8-octahydro1,4:5,8-dimethanoanthracene)]meso-substituents together with the catalytic oxidation activity of their iron or manganese complexes, using hydrogen peroxide as oxidant. 


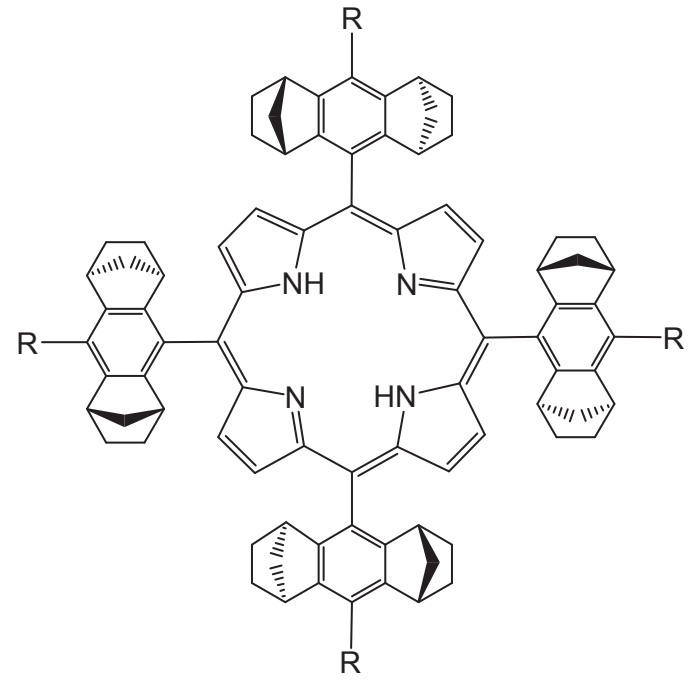

$1-\mathrm{R}=\mathrm{H}$ (Halt )

$2-\mathrm{R}=\mathrm{p}-\mathrm{NO}_{2}\left(\right.$ Halt $\left.\mathrm{p}-\mathrm{NO}_{2}\right)$

$3-\mathrm{R}=\mathrm{p}-\mathrm{NH}_{2}\left(\right.$ Halt $\left.\mathrm{p}-\mathrm{NH}_{2}\right)$

4-R $=\mathrm{p}-\mathrm{NMe}_{2}\left(\mathrm{Halt} \mathrm{p}-\mathrm{NMe}_{2}\right)$

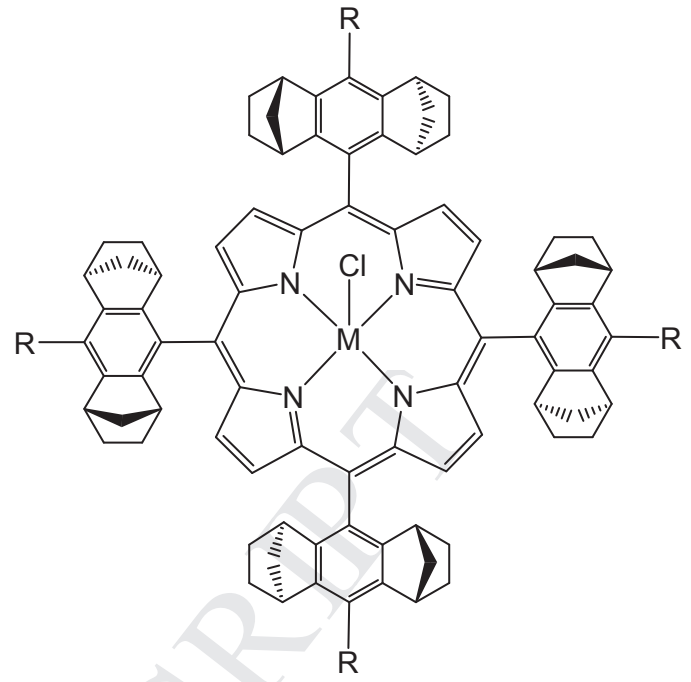

5-M = Fe, $\mathrm{R}=\mathrm{H}(\mathrm{FeCl}$ Halt $)$

6-M $=\mathrm{Fe}, \mathrm{R}=\mathrm{p}-\mathrm{NO}_{2}\left(\mathrm{FeCl}\right.$ Halt $\left.\mathrm{p}-\mathrm{NO}_{2}\right)$

7-M $=\mathrm{Fe}, \mathrm{R}=\mathrm{p}-\mathrm{NMe}_{2}\left(\mathrm{FeCl}\right.$ Halt p-NMe $\left.{ }_{2}\right)$

8-M $=\mathrm{Mn}, \mathrm{R}=\mathrm{H}(\mathrm{MnCl}$ Halt $)$

9-M = Mn, $\mathrm{R}=\mathrm{p}-\mathrm{NO}_{2}\left(\mathrm{MnCl}\right.$ Halt $\left.\mathrm{p}-\mathrm{NO}_{2}\right)$

$10-\mathrm{M}=\mathrm{Mn}, \mathrm{R}=\mathrm{p}-\mathrm{NMe}_{2}\left(\mathrm{MnCl}\right.$ Halt $\left.\mathrm{p}-\mathrm{NMe}_{2}\right)$

Fig. 1. Structures of chiral porphyrins and metal catalysts.

\section{Resultats and discussion}

2.1 Synthesis of chiral porphyrins: Several experiments have been previously reported to electronically modified D4-symmetric metalloporphyrins. ${ }^{32-34}$ In all the cases, the key substituted benzaldehyde, which has only the para position open was used for the porphyrin synthesis. However the efforts were unsuccessful to synthesize the nitro derivative. ${ }^{32}$ Thus we decided to test a direct nitration of the porphyrin instead to modify the chiral aldehyde precursor. In 2004, it was reported a nice system for the regioselective nitration of the phenyl group of meso-tetraphenylporphyrin, using $\mathrm{NaNO}_{2}$ and trifluoroacetic acid. ${ }^{35}$ A similar methodology was herein employed to provide para-tetra-nitro Halterman porphyrin. When a concentrated solution of Halterman porphyrin $\mathbf{1}$ (Figure 1) in trifluoroacetic acid was treated with 12 equiv of sodium nitrite, the porphyrin 2 was obtained with a good yield (87\%). In order to tune the electronic effect of the porphyrin, these nitroporphyrins were converted to the corresponding aminoporphyrins $\mathbf{3}$, by reduction with tin(II) chloride and $\mathrm{HCl}$ in $90 \%$ yield, as previously reported in the literature for the simplest tetraphenylporphyrins. ${ }^{36}$ These chiral porphyrins were then N-dimethylated using iodomethane giving 4 with a method previously described. ${ }^{37}$ All the syntheses are 
summarized in Scheme 1. Classical metallation ${ }^{38}$ of these new porphyrins was carried out in DMF, using the corresponding $\mathrm{FeBr}_{2}$ or $\mathrm{MnBr}_{2}$ salts (see experimental section and Scheme 2).
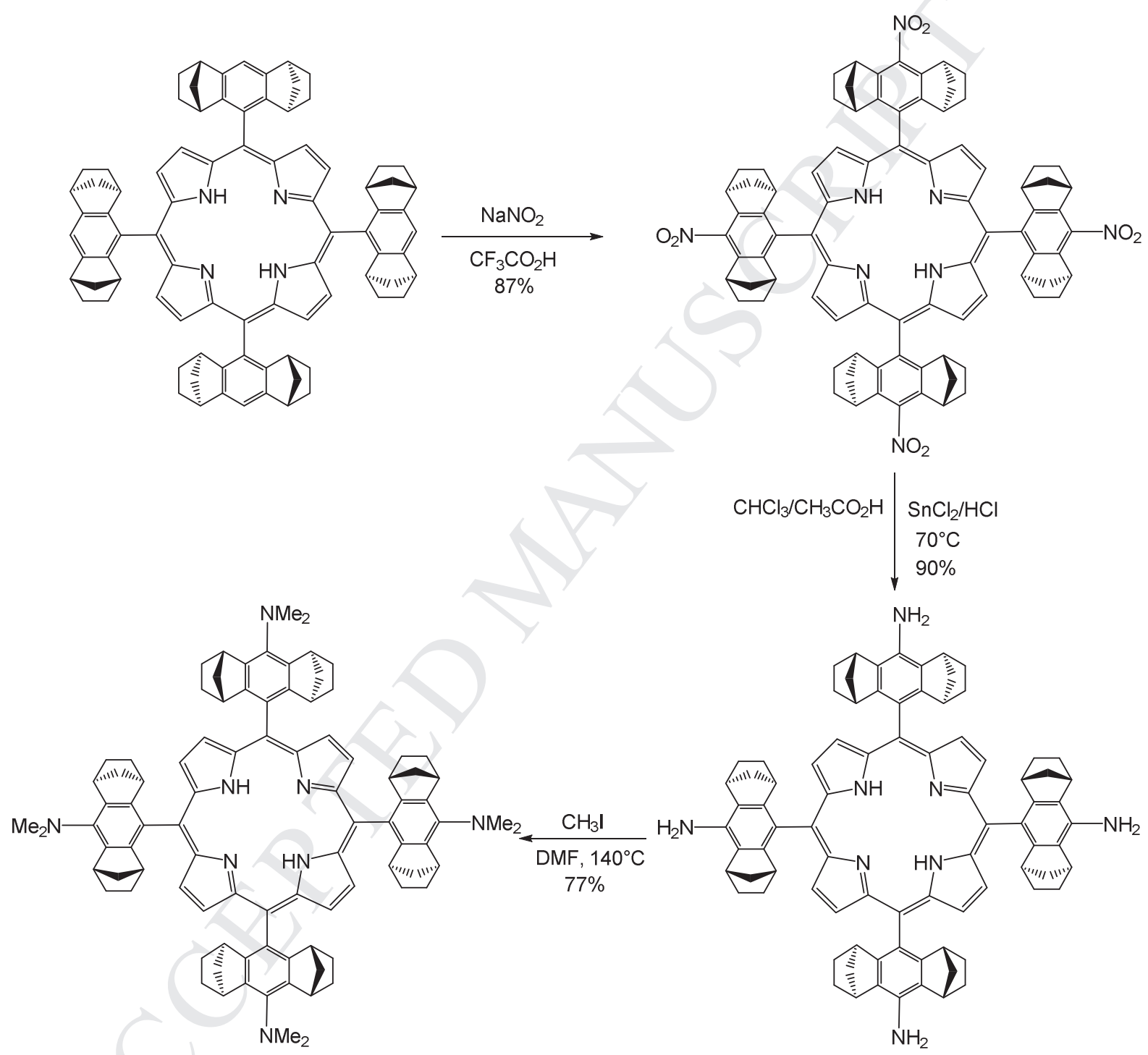

Scheme 1. Synthesis of modified Halterman porphyrins. 

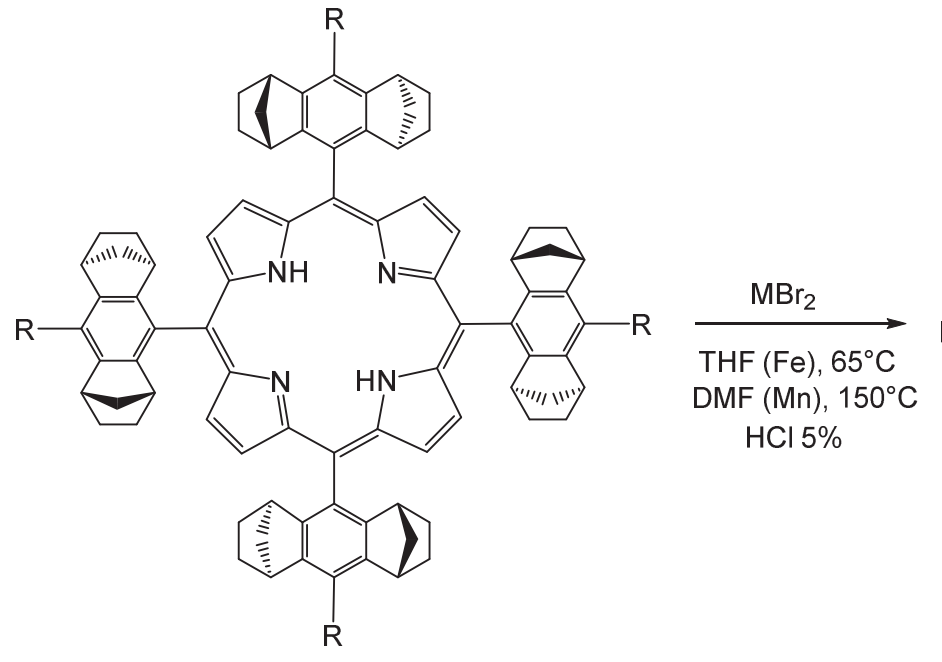

Scheme 2. Metalation of chiral porphyrins.

\subsection{Catalytic epoxidation of alkenes}

Optically active epoxide-containing compounds are of great interest, particularly to synthetic organic chemists and to bioorganic chemists. ${ }^{39}$ Thus the use of hydrogen peroxide has been recently the focus of intense studies as green oxidant for asymmetric oxidation. However, despite a good enantioselectivity, these catalysts suffer from the drawback of moderate stability and there are only few catalytic studies using iron as a metal in the active site. $^{8}$

Following our successful synthesis of the para-substituted Halterman iron porphyrins, their catalytic activity was first tested in the epoxidation of styrene derivatives (Scheme 3 ). Epoxidation was initially catalyzed in presence of imidazole in a mixture of $\mathrm{CH}_{2} \mathrm{Cl}_{2} / \mathrm{CH}_{3} \mathrm{OH}$ (1/1 ratio) by the chiral iron complex $5(\mathrm{R}=\mathrm{H}$, Figure 1$)$ to obtain a reference. Although the asymmetric induction with $\mathbf{5}$ is reasonable (39\%), , the viability of the process is limited owing to a low conversion after 1 hour and 2 hours were necessary to get $30 \%$ conversion. As expected with a ligand bearing electron-donor groups $\left(\mathrm{NMe}_{2}\right)$ (compound 7), epoxidation reactions were also slow with a somewhat increased enantioselectivity (53\%). In contrast, epoxidation with nitro-derivative 6 were fast and a correct conversion (62\%) was obtained after 2 hours. The results are summarized in Table 1. 
Table 1. Asymmetric epoxidation of styrene derivatives catalyzed by $\mathrm{FeCl}$ Halt $\mathrm{p}-\mathrm{R}(\mathrm{R}=\mathrm{H}$ (5), $\left.\mathrm{NO}_{2}(\mathbf{6}), \mathrm{NMe}_{2}(7)\right)-\mathrm{H}_{2} \mathrm{O}_{2}$-Imidazole system ${ }^{\mathrm{a}}$

\begin{tabular}{|c|l|c|c|c|}
\hline Entry & \multicolumn{1}{|c|}{ Substrate } & Catalyst & $\begin{array}{c}\text { Conversion } \\
(\%)^{b}\end{array}$ & $\begin{array}{c}\text { Ee (\%) } \\
(\text { Config) }\end{array}$ \\
\hline 1 & Styrene & $\mathbf{5}$ & 30 & $39(\mathrm{~S})$ \\
\hline 2 & Styrene & $\mathbf{6}$ & 62 & $52(\mathrm{~S})$ \\
\hline 3 & Styrene & $\mathbf{7}$ & 34 & $53(\mathrm{~S})$ \\
\hline 4 & 4-Methylstyrene & $\mathbf{5}$ & 75 & $10(\mathrm{~S})$ \\
\hline 5 & 4-Methylstyrene & $\mathbf{6}$ & 80 & $8(\mathrm{~S})$ \\
\hline 6 & 4-Methylstyrene & $\mathbf{5}$ & 79 & $18(\mathrm{~S})$ \\
\hline 7 & 4-Chlorostyrene & $\mathbf{6}$ & 46 & $28(\mathrm{~S})$ \\
\hline 8 & 4-Chlorostyrene & $\mathbf{7}$ & 18 & $41(\mathrm{~S})$ \\
\hline 9 & 4-Chlorostyrene & $\mathbf{6}$ & 42 & $45(\mathrm{~S})$ \\
\hline 10 & 2-Methylstyrene & $\mathbf{6}$ & 55 & $39(\mathrm{~S})$ \\
\hline 11 & 3-Methylstyrene & $\mathbf{6}$ & 10 & $60(\mathrm{~S})$ \\
\hline 12 & 3-Trifluoromethylstyrene & $\mathbf{6}$ & 3 & $39(\mathrm{~S})$ \\
\hline 13 & 4-Trifluoromethylstyrene & $\mathbf{6}$ & 65 & $60(1 \mathrm{~S}, 2 \mathrm{R})$ \\
\hline 14 & 1,2-Dihydronaphtalene & & & \\
\hline
\end{tabular}

${ }^{a}$ Reaction conditions: catalyst/imidazole/substrate $/ \mathrm{H}_{2} \mathrm{O}_{2}: 1 / 10 / 1000 / 100$ in $1 \mathrm{ml}$ distilled $\mathrm{CH}_{2} \mathrm{Cl}_{2} / \mathrm{MeOH}$ mixture $(0.5 / 0.5)$ under argon for $2 \mathrm{~h} .{ }^{\mathrm{b}}$ Determined by $\mathrm{GC}$ on the crude reaction mixture with traces of aldehyde and based on oxidant. ${ }^{c}$ Determined by GC on a chiral CP-Chirasil-Dex column. ${ }^{\mathrm{d}}$ Absolute configuration of the epoxide of styrene was determined by comparison with the authentic optically pure $(\mathrm{R})-(+)$-styrene oxide. Others were deduced from analogy of the GC behaviour and of the optical rotatory of $(\mathrm{R})-(+)$-styrene oxide.

As shown in Table 1, epoxide conversions between 3\% and $80 \%$ were obtained with enantiomeric excess as high as $60 \%$ for 3-methylstyrene and 1,2-dihydronaphtalene. The key role of imidazole in metalloporphyrin-catalyzed oxygenations with $\mathrm{H}_{2} \mathrm{O}_{2}$, evidenced by Mansuy et al. ${ }^{40}$ in olefin epoxidation with iodosyl benzene is also confirmed herein, since only a very weak conversion $(<5 \%)$ was detected in absence of this ligand. In these reactions, only traces of aldehydes were also detected as by-products. 
Table 2. Asymmetric epoxidation of styrene derivatives catalyzed by $\mathrm{MnCl}$ Halt $\mathrm{p}-\mathrm{R}(\mathrm{R}=$ $\left.\mathrm{H}(\mathbf{8}), \mathrm{NO}_{2}(\mathbf{9}), \mathrm{NMe}_{2}(\mathbf{1 0})\right)-\mathrm{H}_{2} \mathrm{O}_{2}$-Imidazole system ${ }^{\mathrm{a}}$

\begin{tabular}{|c|l|c|c|c|}
\hline Entry & \multicolumn{1}{|c|}{ Substrate } & Catalyst & $\begin{array}{c}\text { Conversion } \\
(\%)^{\mathrm{b}}\end{array}$ & $\begin{array}{c}\text { Ee (\%) } \\
(\text { Config) }\end{array}$ \\
\hline 1 & Styrene & $\mathbf{8}$ & 39 & $45(\mathrm{~S})$ \\
\hline 2 & Styrene & $\mathbf{9}$ & 98 & $48(\mathrm{~S})$ \\
\hline 3 & Styrene & $\mathbf{1 0}$ & 7 & $40(\mathrm{~S})$ \\
\hline 4 & 4-Methylstyrene & $\mathbf{8}$ & 71 & $49(\mathrm{~S})$ \\
\hline 5 & 4-Methylstyrene & $\mathbf{9}$ & 80 & $13(\mathrm{~S})$ \\
\hline 6 & 4-Methylstyrene & $\mathbf{1 0}$ & 12 & $15(\mathrm{~S})$ \\
\hline 7 & 4-Chlorostyrene & $\mathbf{8}$ & 24 & $29(\mathrm{~S})$ \\
\hline 8 & 4-Chlorostyrene & $\mathbf{9}$ & 84 & $40(\mathrm{~S})$ \\
\hline 9 & 4-Chlorostyrene & $\mathbf{1 0}$ & 10 & $32(\mathrm{~S})$ \\
\hline 10 & 2-Methylstyrene & $\mathbf{9}$ & 45 & $37(\mathrm{~S})$ \\
\hline 11 & 3-Methylstyrene & $\mathbf{9}$ & 62 & $51(\mathrm{~S})$ \\
\hline 12 & 3-Trifluoromethylstyrene & $\mathbf{9}$ & 87 & $52(\mathrm{~S})$ \\
\hline 13 & 4-Trifluoromethylstyrene & $\mathbf{9}$ & 80 & $30(\mathrm{~S})$ \\
\hline 14 & 1,2-Dihydronaphtalene & $\mathbf{9}$ & 70 & $55(1 \mathrm{~S}, 2 \mathrm{R})$ \\
\hline
\end{tabular}

${ }^{a}$ Reaction conditions: catalyst/imidazole/substrate/ $\mathrm{H}_{2} \mathrm{O}_{2}: 1 / 24 / 40 / 200$ in $1 \mathrm{ml}$ distilled $\mathrm{CH}_{2} \mathrm{Cl}_{2}$ under argon for $2 \mathrm{~h} .{ }^{\mathrm{b}}$ Determined by GC on the crude reaction mixture with traces of aldehyde. ${ }^{\mathrm{c}}$ Determined by GC on a chiral CP-Chirasil-Dex column. ${ }^{\mathrm{d}}$ Absolute configuration of the epoxide of styrene was determined by comparison with the authentic optically pure (R)$(+)$-styrene oxide. Others were deduced from analogy of the GC behaviour and of the optical rotatory of $(\mathrm{R})-(+)$-styrene oxide.

Prior to this work, we also reported the asymmetric epoxidation of alkenes to give optically active epoxides in water/methanol solutions using a water-soluble sulfonated halterman manganese porphyrin. ${ }^{30}$ It should also be noted that aqueous hydrogen peroxide has been used once as the oxidant for enantioselective epoxidation using a manganeseglycoconjugated porphyrin as the catalyst in biphasic medium, but the enantioselectivity was modest. ${ }^{41}$ For comparison, the herein prepared manganese porphyrins were also tested for epoxidation. The results are summarized in Table 2. As expected, the conversions were generally higher by comparison with the reactions carried out with the iron catalyst. Using the nitro derivative 9 as catalyst, the styrene epoxide was formed with very good conversion (98\%) after two hours and $48 \%$ enantioselectivity. As anticipated from the reactivity of an electrophilic oxo-Mn(V)-porphyrin as active species, the best conversions were obtained with metalloporphyrins bearing electron-withdrawing substituents $\left(\mathrm{NO}_{2}\right)$ whereas no clear trend was evident for optical yields upon changing the para substituent of the Halterman porphyrin ligand. We also investigated the epoxidation of para-substituted styrenes. As shown in Table 
2, para-substitution has a weak effect upon the enantioselectivity of styrene epoxidation, the best ee (55\%) being obtained with 1,2-dihydronaphtalene. It should also be noted that the replacement of iron by manganese has a small detrimental effect on the enantioselectivity.

Other factors affecting the catalytic epoxidation of olefins by chiral water-soluble manganese porphyrins and hydrogen peroxide have been recently investigated by us. ${ }^{30}$ First, it was recognized the presence of water in methanol can be quite successful and that working in basic buffered solutions increases deeply the efficiency of the system. Thus efficient asymmetric oxidation of alkenes with an equimolar amount of $\mathrm{H}_{2} \mathrm{O}_{2}$ with respect of the substrate was possible. ${ }^{30}$ In contrast, a substrate $/ \mathrm{H}_{2} \mathrm{O}_{2}$ ratio of $5 / 1$ was necessary to get a correct conversion in dichloromethane/methanol solvent (see Table 2), showing a somehow better efficient system in water.

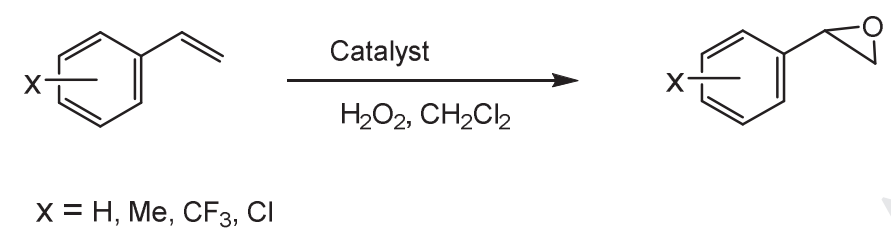

Scheme 3. Epoxidation of alkenes by hydrogen peroxide.

\subsection{Hydroxylation of arylalkanes}

We then first studied the hydroxylation reaction catalyzed by iron porphyrin $\mathbf{5}$, which is clearly an electron-rich iron porphyrin, using $\mathrm{H}_{2} \mathrm{O}_{2}$ as oxidant. Treatment of ethylbenzene (10 equiv) with hydrogen peroxide ( 1 equiv) and a catalytic quantity of catalyst 5 in $\mathrm{H}_{2} \mathrm{O} / \mathrm{MeOH}(1 / 5)$ at room temperature for $1 \mathrm{~h}$ afforded in a very low yield (5\% conversion) as a mixture of (S)-1-phenyl ethanol (47\%) and acetophenone (53\%) (Table 3, entry 3). The enantiopurity of the phenyl ethanol was determined to be $15 \%$ by chiral capillary GC analysis. Due to this detrimental situation and because iodobenzene diacetate $\left(\mathrm{PhI}(\mathrm{OAc})_{2}\right)$ is an efficient terminal oxidant in iron(III)porphyrin complex-catalyzed oxygenation reactions in presence of water, ${ }^{42}$ similar reactions were undertaken, using $\mathrm{PhI}(\mathrm{OAc})_{2}$ instead of $\mathrm{H}_{2} \mathrm{O}_{2}$, for comparison with the manganese system (vide infra). The results, which are summarized in Table 3, show that this oxidant converted ethylbenzene to the corresponding secondary alcohol with a better conversion (41\%) and higher ee $(68 \%)$. Similar yields and ees were obtained for the hydroxylation of substituted ethylbenzene and indane (Table 3 ). 
Table 3. Asymmetric hydroxylation catalyzed by $\mathrm{FeCl}$ Halt $\mathrm{p}-\mathrm{R}\left(\mathrm{R}=\mathrm{H}(\mathbf{5}), \mathrm{NO}_{2}(\mathbf{6}), \mathrm{NMe}_{2}\right.$ (7))- $\mathrm{PhI}(\mathrm{OAc})_{2}$-Imidazole system ${ }^{\mathrm{a}}$

\begin{tabular}{|c|l|c|c|c|c|}
\hline Entry & \multicolumn{1}{|c|}{ Substrate } & Catalyst & $\begin{array}{c}\text { Conversion } \\
(\%)^{\mathrm{b}}\end{array}$ & $\begin{array}{c}\text { Alcohol/ketone } \\
\text { Ratio (\%) }^{\mathrm{b}}\end{array}$ & $\begin{array}{c}\text { Ee (\%) } \\
(\text { Config) }\end{array}$ \\
\hline 1 & Ethylbenzene & $\mathbf{5}$ & 41 & $83 / 17$ & $68(\mathrm{R})$ \\
\hline 2 & Ethylbenzene & $\mathbf{6}$ & 31 & $80 / 20$ & $69(\mathrm{R})$ \\
\hline 3 & Ethylbenzene $^{\mathrm{d}}$ & $\mathbf{5}$ & 5 & $47 / 53$ & $15(\mathrm{R})$ \\
\hline 4 & Ethylbenzene & $\mathbf{7}$ & 35 & $77 / 23$ & $56(\mathrm{R})$ \\
\hline 5 & Indane & $\mathbf{5}$ & 98 & $90 / 10$ & $53^{\mathrm{e}}(\mathrm{R})$ \\
\hline 6 & Indane & $\mathbf{6}$ & 63 & $64 / 36$ & $38^{\mathrm{e}}(\mathrm{R})$ \\
\hline 7 & Indane & $\mathbf{7}$ & 66 & $70 / 30$ & $37^{\mathrm{e}}(\mathrm{R})$ \\
\hline 8 & 4-Ethyltoluene & $\mathbf{5}$ & 33 & $91 / 9$ & $63(\mathrm{R})$ \\
\hline 9 & 4-Ethyltoluene & $\mathbf{6}$ & 18 & $80 / 20$ & $66(\mathrm{R})$ \\
\hline 10 & 4-Ethyltoluene & $\mathbf{7}$ & 16 & $78 / 22$ & $59(\mathrm{R})$ \\
\hline 11 & 2-Ethyltoluene & $\mathbf{6}$ & 11 & $60 / 40$ & $57(\mathrm{R})$ \\
\hline 12 & 3-Ethyltoluene & $\mathbf{6}$ & 27 & $70 / 30$ & $32(\mathrm{R})$ \\
\hline
\end{tabular}

${ }^{\text {a }}$ Reaction conditions: catalyst/imidazole/substrate/ $\mathrm{PhI}(\mathrm{OAc})_{2}: 1 / 10 / 1000 / 100$ in $1 \mathrm{ml}$ mixture $\mathrm{CH}_{2} \mathrm{Cl}_{2} / \mathrm{MeOH} / \mathrm{H}_{2} \mathrm{O}(0.5 / 0.4 / 0.1)$ under argon for $2 \mathrm{~h}$. ${ }^{\mathrm{b}}$ Determined by $\mathrm{GC}$ on the crude reaction mixture and based on oxidant. ${ }^{\mathrm{c}}$ Determined by GC on a chiral CP-Chirasil-Dex column. ${ }^{d}$ With 1 equiv of hydrogen peroxide and 10 equiv of substrate in $\mathrm{H}_{2} \mathrm{O}$ /methanol (1/5). ${ }^{\mathrm{e}}$ Determined by chiral HPLC with a chiralcel OB-H column.

Since it has been reported that $\mathrm{Mn}$ (III)porphyrins, are much better catalysts than $\mathrm{Fe}$ porphyrins for oxygen-atom transfer from $\mathrm{H}_{2} \mathrm{O}_{2}$ to hydrocarbons, ${ }^{40}$ hydroxylation reactions were also carried out with $\mathrm{H}_{2} \mathrm{O}_{2}$ using the electronically modified Halterman Mn catalysts. The stereoselectivity of catalytic hydroxylation of alkylbenzenes and cycloalkylbenzenes by the manganese catalysts is illustrated in Table 4. The hydrocarbons with saturated side chains, i.e. ethylbenzene, and indane, were converted to the corresponding conjugated secondary benzyl alcohols with ees up to $38 \%$ but with a very low conversion. An important amount of $\alpha$-ketones (up to $70 \%$ ) was observed. As an example, treatment of ethylbenzene (1 equiv) with hydrogen peroxide (5 equiv) and a catalytic quantity of complex 9 in $\mathrm{CH}_{2} \mathrm{Cl}_{2}$ at room temperature for $2 \mathrm{~h}$ afforded (11\% conversion) a mixture of 1-phenyl ethanol $(30 \%)$ and acetophenone (70\%) (Table 4, entry 2). The enantiopurity of the phenyl ethanol was determined to be $18 \%$ by chiral capillary GC analysis. As shown in Table 4, 2-, 3-, 4ethyltoluenes and indane are also effective substrates for the 9-catalyzed asymmetric hydroxylation and the corresponding 1-arylethanols were produced in low yields and ees of $21-38 \%$ (entries 5,810,11). As expected for electron donating group, the conversion $(<12 \%)$ was much lower when the dimethylamino group was in the para position of the Halterman 
porphyrin ring (entries 3,6,9). An intermediate situation was observed for catalyst 8. As previously reported with other chiral metalloporphyrins, ${ }^{17}$ the manganese porphyrins provided alcohols with the same configuration in excess but with a much lower selectivity than those obtained with the iron analogs. This was explained by the formation of longer lived manganese radical intermediates after hydrogen atom removal. ${ }^{43}$<smiles>CCc1ccccc1</smiles>

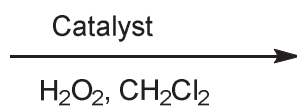

$\mathrm{X}=\mathrm{H}, \mathrm{Me}$<smiles>[X]c1ccc(C(C)=O)cc1</smiles>

Scheme 4. Hydroxylation of arylalkanes by hydrogen peroxide.

Table 4. Asymmetric hydroxylation catalyzed by $\mathrm{MnCl}$ Halt $\mathrm{p}-\mathrm{R}\left(\mathrm{R}=\mathrm{H}(\mathbf{8}), \mathrm{NO}_{2}(\mathbf{9})\right.$, $\left.\mathrm{NMe}_{2}(\mathbf{1 0})\right)-\mathrm{H}_{2} \mathrm{O}_{2}$-Imidazole system ${ }^{\mathrm{a}}$

\begin{tabular}{|c|c|c|c|c|c|}
\hline Entry & Substrate & Catalyst & $\begin{array}{c}\text { Conversion } \\
(\%)^{\mathrm{b}}\end{array}$ & $\begin{array}{c}\text { Alcohol/ketone } \\
\text { Ratio }(\%)^{b}\end{array}$ & $\begin{array}{l}\text { Ee }(\%)^{c} \\
(\text { Config) }\end{array}$ \\
\hline 1 & Ethylbenzene & 8 & 3 & $37 / 63$ & $3(\mathrm{R})$ \\
\hline 2 & Ethylbenzene & 9 & 11 & $30 / 70$ & $18(\mathrm{R})$ \\
\hline 3 & Ethylbenzene & 10 & 2 & $54 / 46$ & - \\
\hline 4 & Indane & 8 & 15 & $70 / 30$ & $7^{\mathrm{d}}(\mathrm{R})$ \\
\hline 5 & Indane & 9 & 11 & $72 / 28$ & $33^{\mathrm{d}}(\mathrm{R})$ \\
\hline 6 & Indane & 10 & 12 & $75 / 25$ & $15^{\mathrm{d}}(\mathrm{R})$ \\
\hline 7 & 4-Ethyltoluene & 8 & 4 & $60 / 40$ & $20(\mathrm{R})$ \\
\hline 8 & 4-Ethyltoluene & 9 & 18 & $80 / 20$ & $38(\mathrm{R})$ \\
\hline 9 & 4-Ethyltoluene & 10 & 2 & $51 / 49$ & $27(\mathrm{R})$ \\
\hline 10 & 2-Ethyltoluene & 9 & 7 & $65 / 35$ & $37(\mathrm{R})$ \\
\hline 11 & 3-Ethyltoluene & 9 & 33 & $52 / 48$ & $21(\mathrm{R})$ \\
\hline
\end{tabular}

${ }^{\text {a }}$ Reaction conditions: catalyst/imidazole/substrate/ $\mathrm{H}_{2} \mathrm{O}_{2}: 1 / 24 / 40 / 200$ in $1 \mathrm{ml}$ mixture $\mathrm{CH}_{2} \mathrm{Cl}_{2}$ under argon for $2 \mathrm{~h} .{ }^{b}$ Determined by GC on the crude reaction mixture. ${ }^{\mathrm{c}}$ Determined by GC on a chiral CP-Chirasil-Dex column. ${ }^{\mathrm{d}}$ Determined by chiral HPLC with a chiralcel OB-H column.

\section{Conclusion}

Our results using complexes 8-10 in catalytic epoxidations show large electronic effects for their reactivity. The $\mathrm{NO}_{2}$-substituted manganese porphyrin catalysts were the best. The better reactivity was attributed to the electron withdrawing effect of the four $\mathrm{NO}_{2}$ substituents in para-position of the four phenyl rings. A similar suggestion was proposed by Berkessel and coll. ${ }^{33}$ for the epoxidation of alkenes catalyzed by ruthenium porphyrin bearing $\mathrm{CF}_{3}$ groups, 
and using 2,6-dichloropyridine $\mathrm{N}$-oxide as oxidant. In contrast, we observe only moderate enantioselectivity changes with the electronically tuned Halterman metalloporphyrins. A different situation was reported in the (salen)Mn-catalyzed asymmetric epoxidation. ${ }^{44}$ In this case, enantioselectivity correlates directly with the electronic properties of the ligand substituents, with complexes bearing electron-donating substituents affording highest ee's. The results obtained with iron catalysts did not show similar effects and moderated reactivity changes were observed. For a deeper understanding of the role of the porphyrin ligand in the herein reactions, a more detailed analysis of the electronic effect will be necessary for a mechanistic interpretation.

\section{Experimental}

\subsection{General}

All reactions were performed under argon. Solvents were distilled from an appropriate drying agent prior to use: $\mathrm{CH}_{2} \mathrm{Cl}_{2}$ from $\mathrm{CaH}_{2}, \mathrm{CHCl}_{3}$ from $\mathrm{K}_{2} \mathrm{CO}_{3}$. Commercially available reagents were used without further purification unless otherwise stated. All reactions were monitored by TLC with Merck precoated aluminum foil sheets (Silica gel 60 with fluorescent indicator UV254). Compounds were visualized with UV light at $254 \mathrm{~nm}$. Column chromatographies were carried out using silica gel from Merck $(0.063-0.200 \mathrm{~mm})$ and neutral aluminium oxide, neutral, Brockmann I, 50-200 $\mu \mathrm{m}, 60 \AA .{ }^{1} \mathrm{H}$ NMR in $\mathrm{CDCl}_{3}$ were recorded using Bruker (Advance 400dpx spectrometer) at $400 \mathrm{MHz}$. High resolution mass spectra were recorded on a Thermo-Fisher Q-Exactive spectrometer in ESI positif mode at the CRMPO at Rennes. Liquid UV-visible spectra were recorded on a UVIKON XL from Biotech. All catalytic reactions were controlled on a Varian CP-3380 GC system that was equipped with a CP-Chirasil-Dex Column (25m, $0.25 \mathrm{~mm}$ I.D.) HPLC analysis was realized on a Varian Prostar 218 system equipped with a Chiralcel OB-H column. The enantiomeric excess of epoxides and alcohols was determined on a Varian CP-3380 GC system. The absolute configuration of epoxides and alcohols was obtained from optical rotations on a PerkinElmer model 341 polarimeter. The Halterman porphyrin 1 was synthetized as previously described in the literature. ${ }^{45}$

\subsection{Porphyrin and metalloporphyrin syntheses}


anthracen-9-yl)-porphyrin 2. Porphyrin 1 (150 mg, $0.131 \mathrm{mmol})$ was dissolved in $9 \mathrm{ml}$ TFA and excess sodium nitrite $(109 \mathrm{mg}, 1.57 \mathrm{mmol}$ ) was added. The mixture was stirred at room temperature for $1 \mathrm{~h}$. The resulting green solution was poured into ice and neutralized with saturated aqueous $\mathrm{NaHCO}_{3}$ until pH8-9. The resulting purple solution was extracted with chloroform and dried over sulfate magnesium. After evaporation, the resulting precipitate was recovered by vacuum filtration, washed with methanol and dried to give $154 \mathrm{mg}$ of a redbrown solid. Yield: $87 \%$.

${ }^{1} \mathrm{H}$ NMR (400 MHz, $\mathrm{CDCl}_{3}$ ): $\delta 8.63$ (s, 8H, $\beta$ pyrrole), 4.18 (s, 8H, CH), $2.72(\mathrm{~s}, 8 \mathrm{H}, \mathrm{CH})$, $1.99\left(\mathrm{~m}, 16 \mathrm{H}, \mathrm{CH}_{2}\right), 1.53\left(\mathrm{~m}, 8 \mathrm{H}, \mathrm{CH}_{2}\right), 1.36\left(\mathrm{~m}, 16 \mathrm{H}, \mathrm{CH}_{2}\right), 1.03\left(\mathrm{~m}, 8 \mathrm{H}, \mathrm{CH}_{2}\right),-2.65(\mathrm{~s}, 2 \mathrm{H}$, $\mathrm{NH}$ pyrrole). UV-vis $\left(\mathrm{CHCl}_{3}\right), \lambda_{\max } \mathrm{nm}\left(\varepsilon \mathrm{M}^{-1} \mathrm{~cm}^{-1}\right) 424\left(395.926 \times 10^{3}\right), 516\left(20.801 \times 10^{3}\right)$, $550\left(7.659 \times 10^{3}\right), 590\left(5.957 \times 10^{3}\right), 645\left(2.176 \times 10^{3}\right)$. HRMS [ES] $\mathrm{m} / z$ calcd for $\mathrm{C}_{84} \mathrm{H}_{75} \mathrm{~N}_{8} \mathrm{O}_{8}: 1323.5702[\mathrm{M}+\mathrm{H}]^{+}$, found: 1323.5700 .

\subsection{2. $5,10,15,20$-Tetrakis-(10-amino-1,2,3,4,5,6,7,8-octahydro-1,4;5,8-dimethano-} anthracen-9-yl)-porphyrin 3. Porphyrin $2(120 \mathrm{mg}, 0.090 \mathrm{mmol})$ was dissolved in a mixture of $22 \mathrm{ml}$ of $\mathrm{CHCl}_{3}$ and $32 \mathrm{ml}$ of acetic acid. Tin(II) chloride (540 mg, $2.85 \mathrm{mmol}$ ) in $32.5 \mathrm{ml}$ concentrated $\mathrm{HCl}$ was then added. The mixture was stirred at $70^{\circ} \mathrm{C}$ for $40 \mathrm{~h}$. The resulting green solution was poured into ice and neutralized with dilute $\mathrm{NH}_{4} \mathrm{OH}$ to $\mathrm{pH} 8-9$. The resulting purple solution was extracted with chloroform and dried over sulfate magnesium. After evaporation, the crude product was purified on neutral aluminium oxide column, using $\mathrm{CHCl}_{3}$ as eluent, to give after evaporation $98 \mathrm{mg}$ of a red-brown solid. Yield: $90 \%$.

${ }^{1} \mathrm{H}$ NMR (400 MHz, $\mathrm{CDCl}_{3}$ ): $\delta 8.68$ (s, 8H, $\beta$ pyrrole), $3.53(\mathrm{~s}, 8 \mathrm{H}, \mathrm{CH}), 2.70(\mathrm{~s}, 8 \mathrm{H}, \mathrm{CH})$, $1.93\left(\mathrm{~m}, 8 \mathrm{H}, \mathrm{CH}_{2}\right), 1.77\left(\mathrm{~m}, 8 \mathrm{H}, \mathrm{CH}_{2}\right), 1.30\left(\mathrm{~m}, 24 \mathrm{H}, \mathrm{CH}_{2}\right), 0.98\left(\mathrm{~m}, 8 \mathrm{H}, \mathrm{CH}_{2}\right),-2.59(\mathrm{~s}, 2 \mathrm{H}$, $\mathrm{NH}$ pyrrole). UV-vis $\left(\mathrm{CHCl}_{3}\right), \lambda_{\max } \mathrm{nm}\left(\varepsilon \mathrm{M}^{-1} \mathrm{~cm}^{-1}\right) 430\left(245.200 \times 10^{3}\right), 522\left(13.176 \times 10^{3}\right)$, $560\left(9.179 \times 10^{3}\right), 596\left(3.664 \times 10^{3}\right), 652\left(4.520 \times 10^{3}\right)$. HRMS [ES] m/z calcd for $\mathrm{C}_{84} \mathrm{H}_{83} \mathrm{~N}_{8}$ : $1203.6735[\mathrm{M}+\mathrm{H}]^{+}$, found: 1203.6734 .

\subsection{3.}

5,10,15,20-Tetrakis-(10-dimethylamino-1,2,3,4,5,6,7,8-octahydro-1,4;5,8dimethano-anthracen-9-yl)-porphyrin 4. Porphyrin 3 (100 mg, $0.083 \mathrm{mmol})$ was dissolved in $10 \mathrm{ml}$ DMF and excess iodomethane $(354 \mathrm{mg}, 2.5 \mathrm{mmol})$ and sodium hydride $(20 \mathrm{mg}, 0.83$ mmol) were added. The reaction mixture was stirred for $15 \mathrm{~min}$ at room temperature and heated at $140^{\circ} \mathrm{C}$ for $30 \mathrm{~min}$. After DMF evaporation under high vacuum, the crude product 
was purified on neutral aluminium oxide column, using $\mathrm{CHCl}_{3}$ as eluent, to give after evaporation $84 \mathrm{mg}$ of a red-brown solid. Yield: $77 \%$.

${ }^{1} \mathrm{H}$ NMR (400 MHz, $\mathrm{CDCl}_{3}$ ): $\delta 8.66$ (s, 8H, $\beta$ pyrrole), 3.83 (s, 8H, CH), $3.10\left(\mathrm{~s}, 24 \mathrm{H}, \mathrm{NMe}_{2}\right.$ ), $2.66(\mathrm{~s}, 8 \mathrm{H}, \mathrm{CH}), 1.90\left(\mathrm{~m}, 8 \mathrm{H}, \mathrm{CH}_{2}\right), 1.81\left(\mathrm{~m}, 8 \mathrm{H}, \mathrm{CH}_{2}\right), 1.40\left(\mathrm{~m}, 8 \mathrm{H}, \mathrm{CH}_{2}\right), 1.25(\mathrm{~m}, 16 \mathrm{H}$, $\left.\mathrm{CH}_{2}\right), 1.01\left(\mathrm{~m}, 8 \mathrm{H}, \mathrm{CH}_{2}\right),-2.59\left(\mathrm{~s}, 2 \mathrm{H}, \mathrm{NH}\right.$ pyrrole). UV-vis $\left(\mathrm{CHCl}_{3}\right), \lambda_{\max } \mathrm{nm}\left(\varepsilon \mathrm{M}^{-1} \mathrm{~cm}^{-1}\right)$ $426\left(266.797 \times 10^{3}\right), 521\left(15.299 \times 10^{3}\right), 557\left(8.576 \times 10^{3}\right), 593\left(4.325 \times 10^{3}\right), 650(3.782 \times$ $\left.10^{3}\right)$. HRMS [ESI]: $m / z$ calcd for $\mathrm{C}_{92} \mathrm{H}_{99} \mathrm{~N}_{8}: 1315.7987[\mathrm{M}+\mathrm{H}]^{+}$, found: 1315.7997

\subsubsection{Chloro(5,10,15,20-Tetrakis-(10-nitro-1,2,3,4,5,6,7,8-octahydro-1,4;5,8-dimethano-} anthracen-9-yl)-porphyrin) iron (III) 6. Porphyrin 2 (50 mg, $0.037 \mathrm{mmol})$ in $10 \mathrm{ml} \mathrm{THF}$ was heated at $65^{\circ} \mathrm{C}$ under argon. $\mathrm{FeBr}_{2} .4 \mathrm{H}_{2} \mathrm{O}(163 \mathrm{mg}, 0.75 \mathrm{mmol})$ was then added and the reaction mixture was stirred until disappearance of the starting material controlled by UV-vis spectroscopy (2h). The reaction mixture was allowed to cool to room temperature and THF evaporated under vacuum. The crude product was dissolved in $15 \mathrm{ml} \mathrm{CHCl}_{3}$ and stirred for 20 min with $5 \mathrm{ml}$ hydrochloric acid (5\%). After phase separation and evaporation of $\mathrm{CHCl}_{3}$, the crude product was purified on silica gel column, using a mixture $\mathrm{CHCl}_{3} / \mathrm{CH}_{3} \mathrm{OH}(9.5 / 0.5)$ as eluent, to give after evaporation $42 \mathrm{mg}$ of a green-brown solid. Yield: 84\%.

UV-vis $\left(\mathrm{CHCl}_{3}\right), \lambda_{\max } \mathrm{nm}\left(\varepsilon \mathrm{M}^{-1} \mathrm{~cm}^{-1}\right) 424\left(70.591 \times 10^{3}\right), 509\left(9.108 \times 10^{3}\right), 579(2.675 \mathrm{x}$ $\left.10^{3}\right)$. HRMS [ESI]: $\mathrm{m} / \mathrm{z}$ calcd for $\mathrm{C}_{84} \mathrm{H}_{72} \mathrm{ClFeN}_{8} \mathrm{O}_{8}: 1411.4511[\mathrm{M}]^{+}$, found: 1411.4509 .

\subsubsection{Chloro(5,10,15,20-Tetrakis-(10-dimethylamino-1,2,3,4,5,6,7,8-octahydro-1,4;5,8-} dimethano-anthracen-9-yl)-porphyrin) iron (III) 7. Porphyrin 4 (40 mg, $0.030 \mathrm{mmol}$ ) in 10 $\mathrm{ml} \mathrm{THF}$ was heated at $65^{\circ} \mathrm{C}$ under argon. $\mathrm{FeBr}_{2} \cdot 4 \mathrm{H}_{2} \mathrm{O}(129 \mathrm{mg}, 0.60 \mathrm{mmol})$ was then added and the reaction mixture was stirred until disappearance of the starting material controlled by UV-vis spectroscopy (2h). The reaction mixture was allowed to cool to room temperature and THF evaporated under vacuum. The crude product was dissolved in $15 \mathrm{ml} \mathrm{CHCl}_{3}$ and stirred for 20 min with $5 \mathrm{ml}$ hydrochloric acid (5\%). After phase separation and evaporation of $\mathrm{CHCl}_{3}$, the crude product was purified on silica gel column, using a mixture $\mathrm{CHCl}_{3} / \mathrm{CH}_{3} \mathrm{OH}$ $(9.5 / 0.5)$ as eluent, to give after evaporation $30 \mathrm{mg}$ of a green-brown solid. Yield: $68 \%$. UV-vis $\left(\mathrm{CHCl}_{3}\right), \lambda_{\max } \mathrm{nm}\left(\varepsilon \mathrm{M}^{-1} \mathrm{~cm}^{-1}\right) 421\left(45.060 \times 10^{3}\right), 510\left(5.504 \times 10^{3}\right), 583(1.686 \mathrm{x}$ $\left.10^{3}\right)$. HRMS [ESI]: $\mathrm{m} / \mathrm{z}$ calcd for $\mathrm{C}_{92} \mathrm{H}_{97} \mathrm{ClFeN}_{8}: 1404.6874[\mathrm{M}+\mathrm{H}]^{+}$, found: 1404.6863 . 


\subsubsection{Chloro(5,10,15,20-Tetrakis-(10-nitro-1,2,3,4,5,6,7,8-octahydro-1,4;5,8-dimethano-} anthracen-9-yl)-porphyrin) manganese (III) 9. Porphyrin 2 (30 mg, $0.022 \mathrm{mmol})$ in $10 \mathrm{ml}$ DMF and 2,6-lutidine $(7-8 \mathrm{mg}, 0.07 \mathrm{mmol})$ was heated at $150^{\circ} \mathrm{C}$ under argon. $\mathrm{MnBr}_{2} .4 \mathrm{H}_{2} \mathrm{O}$ (65 $\mathrm{mg}, 0.22 \mathrm{mmol}$ ) was then added and the reaction mixture was stirred until disappearance of the starting material controlled by UV-vis spectroscopy (8h). The reaction mixture was allowed to cool to room temperature and DMF evaporated under high vacuum. The crude product was dissolved in $10 \mathrm{ml} \mathrm{CHCl}_{3}$ and stirred for 20 min with $5 \mathrm{ml}$ hydrochloric acid (5\%). After phase separation and evaporation of $\mathrm{CHCl}_{3}$, the crude product was purified on silica gel column, using a mixture $\mathrm{CHCl}_{3} / \mathrm{CH}_{3} \mathrm{OH}(19 / 1)$ as eluent, to give after evaporation $21 \mathrm{mg}$ of a green solid. Yield: $65 \%$.

UV-vis $\left(\mathrm{CHCl}_{3}\right), \lambda_{\max } \mathrm{nm}\left(\varepsilon \mathrm{M}^{-1} \mathrm{~cm}^{-1}\right) 480\left(103.453 \times 10^{3}\right), 585\left(9.073 \times 10^{3}\right), 620(8.775 \mathrm{x}$ $10^{3}$ ). HRMS [ESI]: $\mathrm{m} / \mathrm{z}$ calcd for $\mathrm{C}_{84} \mathrm{H}_{72} \mathrm{MnN}_{8} \mathrm{O}_{8} 1375.4848$ [M-Cl] $]^{+}$, found: 1375.4848 .

\subsubsection{Chloro(5,10,15,20-Tetrakis-(10-dimethylamino-1,2,3,4,5,6,7,8-octahydro-1,4;5,8-} dimethano-anthracen-9-yl)-porphyrin) manganese (III) 10. Porphyrin 4 (50 mg, 0.0379 $\mathrm{mmol})$ in $10 \mathrm{ml} \mathrm{DMF}$ and 2,6-lutidine $(12-13 \mathrm{mg}, 0.11 \mathrm{mmol})$ was heated at $150^{\circ} \mathrm{C}$ under argon. $\mathrm{MnBr}_{2} .4 \mathrm{H}_{2} \mathrm{O}(109 \mathrm{mg}, 0.38 \mathrm{mmol})$ was then added and the reaction mixture was stirred until disappearance of the starting material controlled by UV-vis spectroscopy ( $8 \mathrm{~h})$. The reaction mixture was allowed to cool to room temperature and DMF evaporated under high vacuum. The crude product was dissolved in $15 \mathrm{ml} \mathrm{CHCl}_{3}$ and stirred for $20 \mathrm{mn}$ with 5 $\mathrm{ml}$ hydrochloric acid (5\%). After phase separation and evaporation of $\mathrm{CHCl}_{3}$, the crude product was purified on silica gel column, using a mixture $\mathrm{CHCl}_{3} / \mathrm{CH}_{3} \mathrm{OH}(9.5 / 0.5)$ as eluent, to give after evaporation $37 \mathrm{mg}$ of a green solid. Yield: $70 \%$.

UV-vis $\left(\mathrm{CHCl}_{3}\right), \lambda_{\max } \mathrm{nm}\left(\varepsilon \mathrm{M}^{-1} \mathrm{~cm}^{-1}\right) 480\left(70.782 \times 10^{3}\right), 586\left(7.330 \times 10^{3}\right), 624(7.871 \times$ $\left.10^{3}\right)$. HRMS [ESI]: $\mathrm{m} / \mathrm{z}$ calcd for $\mathrm{C}_{92} \mathrm{H}_{96} \mathrm{MnN}_{8} 1367.7133$ [M-Cl] $]^{+}$: found: 1367.7136 .

\subsection{Catalytic oxidation procedure}

4.3.1. General procedure for the catalytic epoxidation reaction of olefins with iron porphyrin catalyst and hydrogen peroxide. Iron porphyrin complex $\mathbf{5}(1.2 \mathrm{mg}, 1 \mu \mathrm{mol})$ and imidazole $(0.34 \mathrm{mg}, 10 \mu \mathrm{mol})$ were placed in a test tube under argon. Then, $1 \mathrm{ml}$ of distilled $\mathrm{CH}_{2} \mathrm{Cl}_{2} / \mathrm{MeOH}$ mixture (0.5/0.5) was added, followed by styrene (104 mg, $1 \mathrm{mmol}$ ). Aqueous $\mathrm{H}_{2} \mathrm{O}_{2}(35 \%)$, (9.7 mg, $\left.100 \mu \mathrm{mol}\right)$ in $0.1 \mathrm{ml} \mathrm{MeOH}$ was added over a period of $1 \mathrm{~h}$ with a syringe-pump. After the addition of all the $\mathrm{H}_{2} \mathrm{O}_{2}$, the reaction was allowed to stir for an 
additional $1 \mathrm{~h}$. The mixture was analyzed by GC for oxidation yield based on $\mathrm{H}_{2} \mathrm{O}_{2}, 30 \%$, and for epoxide enantiomeric excess, $39 \%$ (conditions used: $80^{\circ} \mathrm{C}(1 \mathrm{~min}), 1^{\circ} \mathrm{C} \min ^{-1} 80-120^{\circ} \mathrm{C}$, $2.5^{\circ} \mathrm{C} \mathrm{min}^{-1} 120-180^{\circ} \mathrm{C}$ ). Polarimetric measurement of the oxidation product determined that (S)-(-)-styrene epoxide was formed in excess. Only traces of phenylacetaldehyde were detected.

The reaction and analysis of the other subtrates and catalysts in Table 1 was carried out in an identical manner with that used for styrene epoxidation.

\subsubsection{General procedure for the catalytic epoxidation reaction of olefins with manganese} porphyrin catalyst and hydrogen peroxide. Manganese porphyrin complex 8 (1.2 mg, 1 $\mu \mathrm{mol})$ and imidazole $(0.14 \mathrm{mg}, 4 \mu \mathrm{mol})$ were placed in a test tube under argon. Then, $1 \mathrm{ml}$ of distilled $\mathrm{CH}_{2} \mathrm{Cl}_{2}$ was added, followed by styrene (4.16 mg, $\left.40 \mu \mathrm{mol}\right)$. Aqueous $\mathrm{H}_{2} \mathrm{O}_{2}(35 \%)$, $(19.4 \mathrm{mg}, 200 \mu \mathrm{mol})$ and imidazole $(0.68 \mathrm{mg}, 20 \mu \mathrm{mol})$ in $0.1 \mathrm{ml} \mathrm{MeOH}$ were added over a period of $1 \mathrm{~h}$ with a syringe-pump. After the addition of all the $\mathrm{H}_{2} \mathrm{O}_{2}$, the reaction was allowed to stir for an additional $1 \mathrm{~h}$. The mixture was analysed by GC for oxidation yield, $40 \%$, and for epoxide enantiomeric excess, $45 \%$ (conditions used: $80^{\circ} \mathrm{C}(1 \mathrm{~min}), 1^{\circ} \mathrm{C} \min ^{-1} 80-120^{\circ} \mathrm{C}, 2.5^{\circ} \mathrm{C}$ $\left.\min ^{-1} 120-180^{\circ} \mathrm{C}\right)$. Polarimetric measurement of the oxidation product determined that (S)-(-)styrene epoxide was formed in excess. Only traces of phenylacetaldehyde were detected.

The reaction and analysis of the other subtrates and catalysts in Table 2 was carried out in an identical manner with that used for styrene epoxidation.

\subsubsection{General procedure for the catalytic hydroxylation reaction of arylalkanes with} iron porphyrin catalyst and iodobenzenediacetate. Iron porphyrin complex 5 (1.2 mg 1 $\mu \mathrm{mol})$ and imidazole $(0.34 \mathrm{mg}, 10 \mu \mathrm{mol})$ were placed in a test tube under argon. Then, $1 \mathrm{ml}$ of distilled $\mathrm{CH}_{2} \mathrm{Cl}_{2} / \mathrm{MeOH} / \mathrm{H}_{2} \mathrm{O}$ mixture $(0.5 / 0.4 / 0.1)$ was added, followed by ethylbenzene

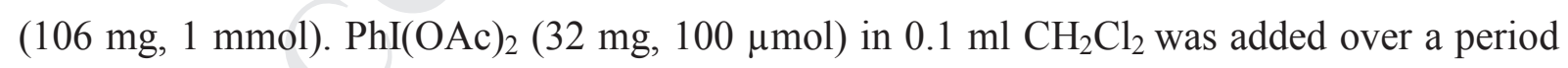
of $1 \mathrm{~h}$ with a syringe-pump. After the addition of all the $\mathrm{PhI}(\mathrm{OAc})_{2}$, the reaction was allowed to stir for an additional $1 \mathrm{~h}$. The mixture was analyzed by GC for oxidation yield based on oxidant, 41\%, alcohol/ketone ratio, 83/17, and alcohol enantiomeric excess, $68 \%$ (conditions used: $\left.80^{\circ} \mathrm{C}(1 \mathrm{~min}), 1^{\circ} \mathrm{C} \min ^{-1} 80-120^{\circ} \mathrm{C}, 2.5^{\circ} \mathrm{C} \mathrm{min}^{-1} 120-180^{\circ} \mathrm{C}\right)$. Polarimetric measurement of the oxidation product determined that (R)-(+)-1-phenylethanol was formed in excess.

The reaction and analysis of the other subtrates and catalysts in Table 3 was carried out in an identical manner with that used for ethylbenzene oxidation. Except for indane, the 
enantiomeric excess was determined by chiral HPLC with a Chiralcel OB-H column: nhexane/isopropanol : 95/5; flow rate : $0.5 \mathrm{ml} \mathrm{min}^{-1}$, detection : $220 \mathrm{~nm}$.

\subsubsection{General procedure for the catalytic hydroxylation reaction of arylalkanes with} manganese porphyrin catalyst and $\mathrm{H}_{2} \mathrm{O}_{2}$. Manganese porphyrin complex 9 (1.4 mg, 1 $\mu \mathrm{mol})$ and imidazole $(0.14 \mathrm{mg}, 4 \mu \mathrm{mol})$ were placed in a test tube under argon. Then, $1 \mathrm{ml}$ of distilled $\mathrm{CH}_{2} \mathrm{Cl}_{2}$ was added, followed by 3-Ethyltoluene (4.80 mg, $\left.40 \mu \mathrm{mol}\right) . \mathrm{H}_{2} \mathrm{O}_{2}(19.4 \mathrm{mg}$, $200 \mu \mathrm{mol})$ and imidazole $(0.68 \mathrm{mg}, 20 \mu \mathrm{mol})$ in $0.1 \mathrm{ml} \mathrm{MeOH}$ were added over a period of 1 $h$ with a syringe-pump. After the addition of all the $\mathrm{H}_{2} \mathrm{O}_{2}$, the reaction was allowed to stir for an additional $1 \mathrm{~h}$. The mixture was analyzed by GC for oxidation yield, 33\%, alcohol/ketone ratio, 52/48, and alcohol enantiomeric excess, $21 \%$ (conditions used: $80^{\circ} \mathrm{C}(1 \mathrm{~min}), 1^{\circ} \mathrm{C} \mathrm{min}^{-1}$ $\left.80-120^{\circ} \mathrm{C}, 2.5^{\circ} \mathrm{C} \mathrm{min}^{-1} 120-180^{\circ} \mathrm{C}\right)$.

The reaction and analysis of the other subtrates and catalysts in Table 4 was carried out in an identical manner with that used for 3-Ethyltoluene oxidation. Except for indane, the enantiomeric excess was determined by chiral HPLC with a Chiralcel OB-H column: nhexane/isopropanol : 95/5; flow rate : $0.5 \mathrm{ml} \mathrm{min}^{-1}$, detection : $220 \mathrm{~nm}$.

\section{References}

1. Lane, B. S.; Burgess, K. Chem. Rev. 2003, 103, 2457-2474.

2. Xia, Q. H.; Ge, H. Q.; Ye, C. P.; Liu, Z. M.; Su, K. X. Chem. Rev. 2005, 105, 16031662.

3. De Faveri, G.; Ilyashenko, G.; Watkinson, M. Chem. Soc. Rev. 2011, 40, 1722-1760.

4. Noyori, R.; Aoki, M.; Sato, K. Chem. Commun. 2003, 1977-1986.

5. Sanderson, W. R. Pure Appl. Chem. 2000, 72, 1289-1304.

6. Arends, I. W. C. E. Angew. Chem. Int. Ed. 2006, 45, 6250-6252.

7. (a) Zhuang, W.; Marigo, M.; Jorgensen, K. A. Org. Biomol. Chem. 2005, 3, 38833885; (b) Nicolas, I. ; Le Maux, P. ; Simonneaux, G. Coord. Chem. Rev. 2008, 252, 727-735; (c) Simonneaux, G.; Le Maux, P.; Chevance, S.; Srour, H. In Handbook of Porphyrin Science; Kadish, K. ; Smith, K. M. ; Guilard, R., Eds ; World Scientific Publishing: Singapore, 2012; vol. 21, pp 377-410. 
8. Srour, H.; Le Maux, P.; Chevance, S.; Simonneaux, G. Coord. Chem. Rev. 2013, 257, 3030-3050.

9. (a) Talsi, E. P.; Bryliakov, K. P. Coord. Chem. Rev. 2012, 256, 1418-1434. (b) Bryliakov, K. P.; Talsi, E. P. Coord. Chem. Rev. 2014, 276, 73-96.

10. Gelalcha, F. G.; Bitterlich, B.; Anilkumar, G.; Tse, M. K.; Beller, M. Angew.Chem. Int. Ed. 2007, 46, 7293-7296.

11. Gelalcha, F. G.; Anilkumar, G.; Tse, M. K.; Brückner, A.; Beller, M. Chem.-Eur. J. 2008, 14, 7687-7698.

12. Lyakin, O. Y.; Ottenbacher, R. V.; Bryliakov, K. P.; Talsi, E. P. ACS Catal. 2012, 2, 1196-1202.

13. White, M. C.; Doyle, A. G.; Jacobsen, E. N. J. Am. Chem. Soc. 2001, 123, 7194-7195.

14. Stingl, K. A.; Weiß, K. M.; Tsogoeva, S. B. Tetrahedron 2012, 68, 8493-8501.

15. Wu, M.; Miao, C.-X.; Wang, S.; Hu, X.; Xia, C.; Kühn, F. E.; Sun, W. Adv. Synth. Catal. 2011, 353, 3014-3022.

16. Groves, J. T.; Myers, R. S. J. Am. Chem. Soc. 1983, 105, 5791-5796.

17. Groves, J. T.; Viski, P. J. Org. Chem. 1990, 55, 3628-3634.

18. Rose, E.; Andrioletti, B.; Zrig, S.; Quelquejeu-Etheve, M. Chem. Soc. Rev. 2005, 34, 573-583.

19. Boitrel, B.; Lecas, A.; Renko, Z.; Rose, E. J. Chem. Soc., Chem. Commun. 1985, 1820-1821.

20. Mansuy, D.; Battioni, P.; Renaud, J. P.; Guerin, P. J. Chem. Soc., Chem. Commun. 1985, 155-156.

21. Collman, J. P.; Zhang, X.; Lee, V. J.; Uffelman, E. S.; Brauman, J. I. Science 1993, 261, 1404-1411.

22. Gross, Z.; Ini, S. J. Org. Chem. 1997, 62, 5514-5521. 
23. Ferrand, Y.; Daviaud, R.; Le Maux, P.; Simonneaux, G. Tetrahedron: Asymmetry 2006, 17, 952-960.

24. Naruta, Y.; Tani, F.; Ishihara, N.; Maruyama, K. J. Am. Chem. Soc. 1991, 113, 68656872 .

25. Simonneaux, G.; Tagliatesta, P. J. Porph. Phtalocyan. 2004, 8, 1166-1171.

26. Kluge, M.; Ullrich, R.; Scheibner, K.; Hofrichter, M. Green Chem. 2012, 14, 440-446.

27. Wang, X.; Peter, S.; Kinne, M.; Hofrichter, M.; Groves, J. T. J. Am. Chem. Soc. 2012, 134, 12897-12900.

28. Le Maux, P.; Simonneaux, G. Chem. Commun. 2011, 47, 6957-6959.

29. Le Maux, P.; Srour, H.; Simonneaux, G. Tetrahedron 2012, 68, 5824-5828.

30. Srour, H.; Le Maux, P.; Simonneaux, G. Inorg. Chem. 2012, 51, 5850-5856.

31. Halterman, R. L.; Jan, S. T.; Nimmons, H. L.; Standlee, D. J.; Khan, M. A. Tetrahedron 1997, 53, 11257-11276.

32. Halterman, R. L.; Jan, S. T.; Abdulwali, A. H.; Standlee, D. J. Tetrahedron 1997, 53, 11277-11296.

33. Berkessel, A.; Kaiser, P.; Lex, J. Chem. Eur. J. 2003, 9, 4746-4756.

34. Ferrand, Y.; Poriel, C.; Le Maux, P.; Rault-Berthelot, J.; Simonneaux, G. Tetrahedron Asymmetry 2005, 16, 1463-1472.

35. Luguya, R.; Jaquinod, L.; Fronczek, F. R.; Vicente, M. G. H.; Smith, K. M. Tetrahedron 2004, 60, 2757-2763.

36. Collman, J. P.; Gagne, R. R.; Reed, C. A.; Halbert, T. H.; Lang, G.; Robinson, W. T. J. Am. Chem. Soc. 1975, 97, 1427-1439.

37. Turk, H.; Erdem, M. J. Porph. Phtalocyan. 2004, 8, 1196-1203.

38. Smith, K. M., Ed. Porphyrins and Metalloporphyrins; Elsevier: Amsterdam, 1975.

39. Gelalcha, F. G. Adv. Synth. Catal. 2014, 356, 261-299. 
40. Battioni, P.; Renaud, J. P.; Bartoli, J. F.; Reina-Artiles, M.; Fort, M.; Mansuy, D. J. Am. Chem. Soc. 1988, 110, 8462-8470.

41. Vilain-Deshayes, S.; Robert, A.; Maillard, P.; Meunier, B.; Momenteau, M. J. Mol. Cat. A: Chem. 1996, 113, 23-34.

42. In, J. H.; Park, S. E.; Song, R.; Nam, W. Inorg. Chim. Acta 2003, 343, 373-376.

43. Groves, J. T.; Kruper, W. J.; Haushalter, R. C. J. Am. Chem. Soc. 1980, 102, 63756377.

44. Palucki, M.; Finney, N. S.; Pospisil, P. J.; Galer, M. L.; Ishida, T.; Jacobsen, E. N. J. Am. Chem. Soc. 1998, 120, 948-954.

45. Halterman, R. L.; Jan, S. T. J. Org. Chem. 1991, 56, 5253-5254. 


\section{Graphical Abstract}

$$
\text { catayst = }
$$

